\title{
PaOla LAMBrini
}

Uniwersytet w Weronie

\section{ACTIO DE DOLO MALO \\ I OCHRONA UMÓW PRAWNIE NIEWIĄŻĄCYCH*}

\section{UWAGI DOTYCZĄCE GENEZY ACTIO DE DOLO MALO}

Podstawowymi źródłami pozwalającymi ustalić, w jakim okresie stworzona została actio de dolo malo są dwa znane fragmenty dzieł Cycerona: fragment de officiis ${ }^{1}$, dzieła wydanego w 45 roku p.n.e., słynny tekst dotyczący oszustwa dokonanego przez syrakuzańskiego bankiera Pythiusa na szkodę rzymskiego ekwity Caniusa, który ówcześnie, czyli pod koniec II wieku p.n.e., nie miał do dyspozycji żadnego środka prawnego, ponieważ nondum C. Aquilius, collega et familiaris meus, protulerat de dolo malo formulas ...; w drugim fragmencie pochodzącym z dzieła de natura deorum mówi się o everriculum malitiarum omnium, iudicium de dolo malo, quod C. Aquillius familiaris noster protulit ${ }^{2}$.

Tradycyjnie na podstawie tych tekstów przyjmowano, że actio de dolo malo została wprowadzona do edyktu przez Aquiliusa Gallusa w 66 roku p.n.e., kiedy jurysta sprawował urząd pretora.

W rzeczywistości w 66 roku p.n.e. C. Aquilius faktycznie sprawował urząd pretora, ale miał za zadanie przewodniczenie quaestio de

* Przekład Anna Tarwacka.

1 Cic., de off. 3,14,60.

2 Cic., de nat. deor. 3,30,74. 
$a m b i t u^{3}$. Nawet jeśli przyjmuje się, że możliwe było jednoczesne posiadanie innego tytułu pretora ${ }^{4}$, wydaje się bardziej prawdopodobne, że Aquilius jedynie zasugerował formułkę actio de dolo malo jako znany jurysta ${ }^{5}$; zapewne zresztą kilkakrotnie, co może wyjaśnić użycie liczby mnogiej formulae ${ }^{6}$. W ten sposób poszerzył się przedział czasowy, w którym umieścić można wprowadzenie skargi z tytułu podstępu do edyktu pretorskiego.

Dla ograniczenia tych ram czasowych, przekonująca wydaje się opinia Federico D'Ippolito ${ }^{7}$, który zauważył, że dialog de natura deorum toczył się w 77 lub 76 roku p.n.e., w domu Aureliusa Cotty, któremu przypisuje się zacytowane zdanie: byłoby niepojętym anachronizmem

${ }^{3}$ Por. Cic., pro Cluentio 53,147

${ }^{4}$ W szczególności jeśli chodzi o pretora do spraw peregrynów, ponieważ wiemy, kto był w tym roku pretorem miejskim (Antonius Hybrida), por. F. SerRaO, La 'iurisdictio' del pretore peregrino, Milano 1954, s. 106 i n.

5 O. Karlowa, Römische Rechtsgeschichte, II, Leipzig 1901, s. 1069 i n. wskazuje na fakt, że Cycero używa słowa proferre, a nie proponere, co wskazywałoby, że nie chodziło tu tyle o bezpośrednie wprowadzenie środków procesowych, co o wyrażenie potrzeby ich wprowadzenia przez jurysprudencję.

${ }^{6}$ Najwięcej poparcia uzyskuje opinia A. Pernice, 'Labeo'. Römisches Privatrecht im ersten Jahrhundert der Kaiserzeit, II, $1^{2}$, Halle 1895, s. 198, według którego Cycero miał na myśli zarówno actio jak i exceptio doli. Było jednak wiele prób uzasadnienia zastosowania wyrażenia formulae: jak twierdzi A.F. RudoRfF, Über die Octavianische Formel, «ZGRW» 12 (1845), s. 131 i n., liczba mnoga miała wskazywać na różne zastosowania actio de dolo. O. Lenel, Das Edictum Perpetuum ${ }^{3}$, Leipzig 1927 s. 115 przyp. 1, natomiast zwraca uwagę na wielość skarg wprowadzonych przez Aquiliusa Gallusa. Por. też M. BRUTTI, La problematica del dolo processuale nell'esperienza romana I, Milano 1973, s. 129 przyp. 1, dla którego zwrot formulae oznacza „, rimedi, non specificamente individuati, attraverso i quali viene fondata da Aquilio, al di dentro di una denominazione risalente qual'è quella di dolus, una nuova categoria con la quale opererà il pretore, e che diverrà oggetto di analisi da parte dei giuristi”.

${ }^{7}$ F. D'Ippolito, Questioni decemvirali, Napoli 1993, s. 175 (powtórzone w Servio e le XII Tavole, [w:] Per la storia del pensiero giuridico romano. Dall'età dei pontefici alla scuola di Servio. Atti del Seminario di S. Marino, 9 gennaio 1993, Torino 1994, s. 32); Sulla data dell' 'actio de dolo', "Labeo» 41 (1995), s. 247 i n. (='Fraterna munera'. Studi in onore di Amirante, Salerno 1998, s. 161 i n.); Insidie manualistiche, «Index»32 (2004), s. 257. 
kazać mu mówić o skardze z tytułu podstepu, jeżeli ta zostałaby wprowadzona przez Aquiliusa dopiero 10 lat później. Skarga ta musiała zatem zostać stworzona przynajmniej kilka lat przed ta datą ${ }^{8}$ Biorąc pod uwagę, że Aquilius urodził się w 110 roku p.n.e., można przypuszczać, że skarga została umieszczona w edykcie między 90 a 80 rokiem p.n.e.

\section{UWAGI DOTYCZACE CECH CHARAKTERYSTYCZNYCH FORMUŁKI ACTIO DE DOLO MALO 9}

Actio de dolo była skargą pretorska, z intentio in factum concepta. Przyjmuje się, że jej funkcja była przede wszystkim penalna ${ }^{10}$, nawet jeśli zasądzenie opiewało in simplum, w kwocie równej wartości ekonomicznej szkody poniesionej przez powoda.

8 Por. M. Bretone, Labeone e l'editto, «Sem. Compl.» 5 (1993), s. 25 przyp. 25; A. Corbino, Il caso di Visellio Varrone e Otacilla Laterense (Val. Max. 8,2,2), [w:] 'Iuris vincula'. Studi in onore di Talamanca, II, Napoli, 2001, s. 253; R. CARDILli, La 'buona fede' come principio di diritto dei contratti: diritto romano e America Latina, «Roma e America» 13 (2002), s. 136 przyp. 36 i s. 141 przyp. 53 (powtórzone w 'Bona fides' tra storia e sistema, Torino 2004, s. 1 i n.); C.A. CANnATA, Corso di istituzioni di diritto romano, II.1, Torino 2003, s. 22 przyp. 20; R. FercIA, Appunti su funzione e struttura formulare dell' 'actio de dolo', [w:] Studi economico-giuridici in memoria di F. Ledda, I, Torino 2004, s. 427, nt. 27; A. Burdese, L'eccezione di dolo generale da Aquilio a Labeone, [w:] L'eccezione di dolo generale. Diritto romano e tradizione romanistica, red. L. GAROFALO, Padova 2006, s. 65 i n.

9 Oto rekonstrukcja klauzuli edyktalnej i formułki (cfr. O. LENEL, Edictum, cit., s. 114): Quae dolo malo facta esse dicentur, si de his rebus alia actio non erit et iusta causa esse videbitur, intra annum, cum primum experiundi potestas fuerit, iudicium dabo. Si paret dolo malo N. Negidii factum esse ut A. Agerius N. Negidio fundum quo de agitur mancipio daret neque plus quam annus est cum experiundi potestas fuerit neque ea res arbitrio iudicis restituetur, quanti ea res erit tantam pecuniam iudex N. Negidium A. Agerio condemnato; si non paret absolvito.

${ }^{10}$ Nawet jeśli chodzi o osłabioną penalność; por. L. VACCA, Delitti privati e azioni penali nel principato, «ANRW» II.14 (1982), s. 702; G. RosseTtI, Problemi e prospettive in tema di 'struttura' e 'funzione' della azioni penali private, «BIDR» 96-97 (1993-94), s. 342 i n.a; P. VocI, Azioni penali e azioni miste, «SDHI» 64 (1998), s. $1 \mathrm{i} \mathrm{n}$. 
$\mathrm{Z}$ drugiej strony, była skargą infamującą ${ }^{11}$, a zatem zasądzenie niosło ze sobą, w sferze prawa publicznego, utratę zarówno ius suffragii jak i ius honorum, a sferze prawa prywatego zakaz postulare pro aliis (jako adwokat, cognitor, procurator) i bycia reprezentowanym w sadzie przez kogoś innego oraz, w niektórych przypadkach, niezdolność do skaładania zeznań.

Poza tym, była to jedna z nielicznych skarg arbitrarnych in personam $^{12}$. Wydaje się, że istnienie arbitratus de restituendo należy wyjaśnić jako ostatnią szansę umożliwiającą pozwanemu uniknięcie infamii. Oprócz tego, jeśli restitutio byłaby niemożliwa, nie wprowadzano arbitratus, a zasądzenie opiewało in id quod intersit actoris ${ }^{13}$, bez - jak się wydaje - negatywnej konsekwencji w postaci infamii.

Skarga miała poza tym termin przedawnienia ustalony na rok, przedłużony za Konstantyna do dwóch lat ${ }^{14}$.

Skargi z tytułu podstępu udzielano jedynie po dokonaniu causae cognitio $^{15}$, czyli po dokładnym zbadaniu sytuacji dokonanym przez pretora in iure; było to konieczne $\mathrm{z}$ różnych powodów.

Przede wszystkim właśnie w związku z tym, że skarga z tytułu podstępu była infamująca i dlatego pretor musiał w konkretnych przypadkach sprawdzać, przeciwko komu była wytaczana. Actio de dolo nie

11 Por. A. D'Ors, Una nueva lista de acciones infamantes, [w:] 'Sodalitas'. Scritti in onore di Guarino, 6, Napoli 1984, s. 2575 i n.; H. Blanch, Nota a propósito de la 'actio de dolo' y su carácter infamante, [w:] Estudios en homenaje al profesor J. Iglesias, red. J. Roset Esteve, I, Madrid 1988, s. 1151.

12 B. Biond, Studi sulle 'actiones arbitrariae' e l' arbitrium iudicis', Palermo 1912, s. 83 odrzucił tę cechę: wychodząc z założenia, że celem subsydiarności było uniknięcie skutków infamii stwierdził, iż taki cel nie miałby sensu, jeśli arbitratus pozwalałby pozwanemu uniknąć zasądzenia, a, co za tym idzie, infamii; zobaczymy jednak, że ratio subsydiarności była zapewne inna.

13 Por. Paul. 11 ad ed. D. 4,3,18,1: Non tamen semper in hoc iudicio arbitrio iudicis dandum est: quid enim si manifestum sit restitui non posse (veluti si servus dolo malo traditus defunctus sit) ideoque protinus condemnari debeat in id quod intersit actoris?

14 Por. C. 2,20,8; por. M. Амецотті, La prescrizione delle azioni in diritto romano, Milano 1958, s. 45 i 57.

$15 \mathrm{Na}$ ten temat por. przede wszystkim R. MARTINI, Il problema della 'causae cognitio' pretoria, Milano 1960. 
mogła bowiem być udzielana dzieciom w stosunku do rodziców czy też wyzwoleńcom w stosunku do patronów; w tych i podobnych przypadkach należało przyznać actio in factum verbis temperanda, ut bonae fidei mentio fiat ${ }^{16}$. $\mathrm{Z}$ tego samego powodu skarga nie mogła być przyznana w przypadku śmiesznie niskiej szkody ${ }^{17}$.

Poza tym, w czasie tego rozpoznania pretor powinien wstępnie ustalić brak innego środka procesowego, którego można by było użyć dla ochrony powoda, ponieważ skarga ta była subsydiarna (si alia actio non erit).

Wreszcie, pretor powinien sprawdzić istnienie uzasadnionych powodów pozwalających przyznać actio de dolo w konkretnym przypad$\mathrm{ku}$ (si iusta causa esse videbitur).

\section{3. 'SI ALIA ACTIO NON ERIT': ROZSZERZENIE ZASADY SUBSYDIARNOŚCI W OKRESIE KLASYCZNYM I JEGO POWODY}

Wymóg subsydiarności spowodował poważne dyskusje w literaturze romanistycznej; słynna jest konfrontacja dotycząca tej problematyki, której protagonistami na początku lat $60 \mathrm{XX}$ wieku byli Bernardo Albanese $^{18}$ i Antonio Guarino ${ }^{19}$. Najwieksze wątpliwości budzą kwestie związane z rozszerzeniem w epoce prawa klasycznego zasady subsydiarności i przyczyny uzasadniające je.

${ }_{16}$ Tak Ulp. 11 ad ed. D. 4,3,11,1.

17 Por. Ulp. 11 ad ed. D. 4,3,9,5.

18 B. Albanese, La sussidiarietà dell' 'actio de dolo', «AUPA» 28 (1961), s. 173 i n.; TenżE, Ancora in tema di sussidiarietà dell' 'actio de dolo', «Labeo» 9 (1963), s. 42 i n. (teraz w Scritti giuridici, I, Palermo 1991, s. 331 i n.). Ostatnio por. B. Kupisch, 'Actio famosa'. Zur Subsidiarität der 'actio de dolo' bei 'dolus' im Prozess, [w:] Beiträge zur Rechtswissenschaft. Festschrift Stree und Wessels, Heidelberg 1993, s. $1187 \mathrm{in}$.

19 A. Guarino, La sussidiarietà dell' 'actio de dolo', «Labeo» 8 (1962), s. 270 i n. (teraz w Pagine di diritto romano, VI, Napoli 1995, s. 281 i n., do którego odnoszą się kolejne cytowania). 
Bernardo Albanese ${ }^{20}$ naświetlił podwójną interpretację tego kryterium, którą można przypisać jurysprudencji klasycznej. Jest ona skierowana $\mathrm{z}$ jednej strony na zawężenie zakresu zastosowania skargi $\mathrm{z}$ tytułu podstępu sugerując pod terminem alia actio jakikolwiek środek ochrony dostępny dla ofiary podstępu ${ }^{21}$, a zatem również zarzut procesowy, interdykt, restitutio in integrum czy wreszcie skargę wobec osoby trzeciej nie będącej autorem podstępu ${ }^{22}$. Z drugiej strony, odnaleźć można inną drogę interpretacji skierowaną na rozszerzenie zakresu zastosowania skargi z tytułu podstępu, dzięki wprowadzonej przez Labeona zasadzie, zgodnie z którą actio de dolo udzielić można również w przypadku wattpliwości co do istnienia jakiegoś innego środka ochrony ${ }^{23}$.

Albanese podtrzymywał w szczególności klasyczne pochodzenie źródeł ${ }^{24}$ dotyczących przyznania actio de dolo w przypadku, kiedy istniała możliwość wytoczenia innej skargi przeciwko osobie trzeciej nie będącej autorem podstepu, ale niewypłacalnej ${ }^{25}$. Guarino bronił nato-

20 B. Albanese, La sussidiarietà, cit., s. 173 i n.

${ }^{21}$ Skarga z tytułu podstępu była także wykluczona, kiedy do dyspozycji była inna skarga ograniczona terminem przedawnienia, a powód pozwolił minąć terminowi albo zrzekł się jej, przynajmniej jeśli fakty te zostały podniesione przez stronę przeciwną: por. Ulp. 11 ad ed. D. 4,3,1,6-7.

22 Por. Ulp. 11 ad ed. D. 4,3,1,8; Paul. 11 ad ed. D. 4,3,2; Ulp. 11 ad ed. D. 4,3,3; Paul. 11 ad ed. D. 4,3,4.

${ }^{23}$ Ulp. 11 ad ed. D. 4,3,7,3: Non solum autem si alia actio non sit, sed et si dubitetur an alia sit, putat Labeo de dolo dandam actionem et adfert talem speciem. qui servum mihi debebat vel ex venditione vel ex stipulatu, venenum ei dedit et sic eum tradidit: vel fundum, et dum tradit, imposuit ei servitutem vel aedificia diruit, arbores excidit vel extirpavit: ait Labeo, sive cavit de dolo sive non, dandam in eum de dolo actionem, quoniam si cavit, dubium est, an competat ex stipulatu actio. sed est verius, si quidem de dolo cautum est, cessare actionem de dolo, quoniam est ex stipulatu actio: si non est cautum, in ex empto quidem actione cessat de dolo actio, quoniam est ex empto, in ex stipulatu de dolo actio necessaria est. Dla egzegezy tego tekstu niech mi się będzie wolno odwołać do mojego eseju Labeone, l'azione di dolo e l'inadempimento: per una rilettura critica di D. 4.3.7.3 (Ulp. 11 ad ed.), «Iura» 57 (2008-2009), s. 226 i n.

24 Por. Ulp. 11 ad ed. D. 4,3,5; Gai. 4 ad ed. prov. D. 4,3,6.

25 Podobnie A. Masi, Insolvenza dell'obbligato e susidiarietà dell' 'actio de dolo', «Studi Senesi» 74 (1962), s. 40 i n. 
miast tezy Pringsheima ${ }^{26}$, utrzymując charakter „,non classico, anche se non decisamente giustinianeo"27 powyższej reguły. Biorąc pod uwagę ten aspekt zasady subsydiarności, ja podzielam zdecydowanie opinię Albanese, ponieważ bardziej przekonujące od analiz pojedynczych tekstów często opartych na słabej argumentacji, wydają mi się obserwacje dotyczące przyjętego w okresie poklasycznym stosunku do omawianej skargi: sposób myślenia typowy dla nowego procesu extra ordinem, $\mathrm{z}$ tendencją do udzielania ochrony w przypadkach jej godnych, prowadzi raczej do zawężenia, a nie rozszerzenia pola zastosowania skargi z tytułu podstępu, ponieważ odczuwa się mniejszą potrzebę jej udzie$\operatorname{lania}^{28}$. Nie dałoby się zatem wyjaśnić, dlaczego w okresie poklasycznym miano by wprowadzić dwa nowe przypadki zastosowania actio de dolo w sytuacji niewypłacalności osoby trzeciej.

Jeśli chodzi o przyczynę subsydiarności actio de dolo, nie wydaje się ona wynikać z charakteru infamującego skargi ${ }^{29}$, jako że wówczas nie można by było wyjaśnić, dlaczego subsydiarność nie została przewidziana dla innych skarg infamujących i nie można by było zrozumieć interpretacji jurystów skierowanej na przyznanie skargi również wówczas, gdy pojawiały się jedynie wattpliwości co do istnienia innego środka ochrony, interpretacji, u źródeł której z pewnością nie leża-

26 F. Pringsheim, Subsidiarität und Insolvenz, «ZSS» 41 (1920), s. 254 i n.

27 A. Guarino, La sussidiarietà, cit., s. 284.

28 Jak zauważa B. AlbANEse, La sussidiarietà, cit., s. 315: „un esame attento in ordine a tutte le fonti postclassiche mostra che l'a. de dolo è quasi del tutto ignorata"; można zaobserwować brak zainteresowania skargą z tytułu podstępu w okresie poklasycznym. „Di questo disinteresse sono segni evidenti la totale assenza di provvedimenti imperiali d'un qualche rilievo in tema di $a$. de dolo (l'ultimo è C. 2,20,8, di Costantino che aumenta il termine di prescrizione a due anni), nonché l'atteggiamento di Giustiniano... che conserva le testimonianze classiche, ma non mostra alcuna tendenza innovativa sostanziale”. Zmiany w tekstach są poza tym ,volte all'eliminazione di controversie classiche o di dubbi, strettamente connessi al delicato sistema del processo formulare".

29 Jak wydaje się wynikać z Ulp. 11 ad ed. D. 4,3,1,4: Ait praetor: ,si de his rebus alia actio non erit". merito praetor ita demum hanc actionem pollicetur, si alia non sit, quoniam famosa actio non temere debuit a praetore decerni, si sit civilis vel honoraria, qua possit experiri ... . 
ło przekonanie o wadze samej skargi. Jak wcześniej wspomniano, infamujący charakter skargi wyjaśnia niemożność jej zastosowania wobec osób, którym należało okazywać szacunek.

Ratio uzasadniającą zasadę subsydiarności jest $\mathrm{z}$ pewnością fakt, że ma ona charakter środka generalnego mającego zastosowanie we wszystkich przypadkach, które byłyby inaczej pozbawione ochrony ${ }^{30}$.

Aquilius Gallus wprowadzając ten środek zastosował „costruzione geniale, perché, per la prima volta, nel sistema romano, si esce dai ristretti termini di una fattispecie individuata tipicamente, per considerare illecito in sé e per sé un atteggiamento generico malizioso"31; żeby jednak nie wkraczać na obszary posiadające już ochronę, należało przewidzieć subsydiarność tego nowego środka

Skarga de dolo dotyczy zachowań, które inaczej ,sfuggirebbero alle reti che l'ordinamento ha apprestato per assicurare 1'eliminazione delle ingiustizie. Con l'introduzione dell'actio de dolo, l'ordinamento mostra di avere coscienza della propria necessaria imperfezione. ... I comportamenti sanzionati con l'actio de dolo non sono di per sé illeciti: è l'editto che la prevede a farne degli illeciti, con l'ultima norma, la norma di chiusura del sistema" ${ }^{2}$, i musi koniecznie być subsydiarna.

\section{4. 'SI IUSTA CAUSA ESSE VIDEBITUR': KONCEPCJA PODSTĘPU W ACTIO DE DOLO DE MALO}

Po upewnieniu się o braku innych dostepnych środków, pretor zastrzegał sobie możliwość odmówienia przyzania actio de dolo, i - co za tym idzie - w praktyce jakiejkolwiek ochrony prawnej, jeżeli uznałby, że brakuje słusznej przyczyny, czyli w gruncie rzeczy podstępu.

Podstęp był bez wattpienia podtawową przesłanką przyznania actio de dolo; to pojęcie było jednak bardzo elastyczne i podlegało dopre-

30 Por. O. Karlowa, Römische Rechtsgeschichte, II, cit., s. 1070: „nicht wegen des infamierenden Charakters der neuen actio, sondern weil Aquilius nicht in das von schon vorhandenen Klagen okkupierte Feld eingreifen konnte und wollte ...”.

31 B. Albanese, La sussidiarietà, cit., s. 308.

32 Tak C.A. Cannata, Corso, II.1, cit., s. 30 i n. 
cyzowaniu tylko na podstawie kontekstu zastosowania ${ }^{33}$. Właśnie dlatego, że kategoria podstępu w ramach actio de dolo (podobnie zresztą jak w przypadku exceptio doli) nie pozwalała w sposób ogólny i abstrakcyjny wyróżnić przypadków zastosowania, szczególnie potrzebne było wstępne dochodzenie pretorskie ${ }^{34}$.

W związku z tym, przydatne może być przypomnienie, że pojęcie podstępu w actio de dolo malo przez długi czas podlegało założeniu polegającemu na utożsamianiu go z oszustwem kontraktowym ${ }^{35}$. Za poklasyczne uznawano wszelkie zastosowania niewątpliwie pozakontraktowe, o których przeczytać można w Corpus Iuris ${ }^{36}$.

To Mitteis, w początkach XX stulecia ${ }^{37}$, zwrócił uwagę, że już w epoce klasycznej skarga z tytułu podstępu przynawana była nie tylko w przypadkach jawnego oszustwa, ale także przeciwko zachowaniom polegającym jedynie na osiagnięciu korzyści sprzecznym z fides ${ }^{38}$ w sytuacji sprzyjającej.

33 Na temat ogólnej koncepcji podstępu por. L. TER BEEK, 'Dolus'. Een semantischjuridische studie, Nijmegen 1999, wraz z recenzją: R. KNÜTEL, «ZSS», 119 (2002), s. 651.

34 Nie umniejsza to znaczenia innowacji, jako że, it is one thing to have to go to the praetor to ask for an ad hoc remedy which would always, especially to laymen, seem very uncertain even when it was not, quite another to know that there is a general action covering fraud as defined by the praetor": A. WATSON, 'Actio de dolo' and 'actiones in factum', «ZSS» 78 (1961), s. 395.

35 Por. praecipue F. LitTen, Zum dolus-Begriff in der 'actio de dolo', [w:] Festgabe für K. Güterbock, Berlin 1910, s. 257 i n.; F. PALumbo, L' azione di dolo. Diritto romano e vigente, Napoli 1935, s. 9 i n.; G. Longo, Contributi alla dottrina del dolo, Padova 1937, s. 3 i n.; M. NäF-Hofmann, Zur objektiven Ausweitung der 'actio de dolo' im römischen und gemeinen Recht, Winterthur 1962, passim; G. LonGo, Sul regime giustinianeo dell' 'actio de dolo', [w:] Studi in onore di Zingali, Milano 1965, s. 461 i n.

36 Wśród najważniejszych por. Ulp. 11 ad ed. D. 4,3,9,3; Paul. 11 ad ed. D. 4,3,18,35; Pap. 37 quaest. D. 4,3,19; Paul. 11 ad ed. D. 4,3,20 pr.; Ulp. 42 ad Sab. D. 4,3,34.; Ulp. 5 opin. D. 4,3,38; Ulp. 7 ad Sab. D. 7,4,5,3; Ulp. 25 ad ed. D. 11,7,14,2; Pomp. 22 ad Sab. D. 19,5,16,1; Paul. 5 quaest. D. 19,5,5,2-3; C. 2.20.4.

37 L. MitTeIs, Römisches Privatrecht bis auf die Zeit Diokletians, I, Leipzig 1908, s. $320 \mathrm{in}$.

${ }^{38}$ Co nie oznacza zrównania $\mathrm{z}$ tym, co zostanie usankcjonowane w ramach iudicia bonae fidei: ,uns genügt die Überlegung, daß die Semantik des dolus malus 
Później opinia ta została przejęta i zaczęła być dominująca ${ }^{39}:$, la più intensa e fruttifera opera dell'interpretazione giurisprudenziale appare diretta ad estendere l'esperibilità dell'actio e dell'exceptio doli al di fuori del suo primitivo campo di applicazione; al di fuori cioè, di quei casi in cui vi fosse stato raggiro nella conclusione del negozio giuridico, per ricomprendervi quelle fattispecie in cui il comportamento malizioso di uno dei soggetti, in qualsiasi momento successivo, avesse determinato un torto non perseguibile per altra via" 40 .

W fundamentalnej pracy Massimo Brutti ${ }^{41}$ uściślone zostało, że od momentu wprowadzenia tego środka ochrony pojęcia podstępu nie należało ograniczać do sfery kontraktowej: zostało także zauważone, że dzieła Cycerona i źródła, które miały wskazywać na stopniowe rozszerzanie pojęcia podstępu ${ }^{42}$ są zbyt zbliżone w czasie, żeby z tych pierwszych można było wydobyć pierwotną koncepcję podstępu w stosunku

Möglichkeiten der Konkretisierung eröffnet, die der bona fides ... fehlen" (tak D. NöRR, Probleme der Eviktionshaftung im klassischen römischen Recht, «ZSS» 121 (2004), s. 176); w podobnym sensie zob. obserwacje R. FIORI, Eccezione di dolo generale ed editto asiatico di Quinto Mucio: il problema delle origini, [w:] L'eccezione di dolo generale. Diritto romano e tradizione romanistica, red. L. Garofalo, Padova, 2006, s. $65 \mathrm{in}$.

39 Por. M. Kaser, Römisches Privatrecht ${ }^{2}$, II, München 1975, s. 91 przyp. 56; A. WACKe, Sul concetto di 'dolus' nell' 'actio de dolo', «Iura» 28 (1977), s. 10 i n. (= Zum 'dolus'-Begriff der 'actio de dolo', «RIDA» 27 (1980), s. 349 i n.); G. MacCormack, 'Dolus' in Republican Law, «BIDR» 88 (1985), s. 1 i n.; Tenże, 'Dolus' in the Law of the Early Classical Period (Labeo-Celsus), «SDHI», 52 (1986), s. 236 i n.; TenżE, Dolus in Decisions of the Mid-Classical Jurist, «BIDR»96-97 (1993-1994), s. 84 i n.; TENŻE, Roman Jurisprudence and Interpretation: on 'dolus' as Ground of the Classical 'actio de dolo', [w:] Nozione formazione e interpretazione del diritto dall'età romana alle esperienze moderne. Ricerche dedicate al professor Filippo Gallo, Napoli 1997, s. 539 i n.

40 Tak G.I. Luzzatto, s.v. Dolo (diritto romano), «ED» 13 (1964), s. 714.

${ }^{41}$ M. Brutti, La problematica, cit., passim. Pewne przyczynki już w B. Albanese, La sussidiarietà, cit., s. 173 i n. oraz w A. WATSON, The Law of Obligations in the Later Roman Republic, Oxford 1965, s. 261.

${ }^{42}$ W szczególności Paul. 11 ad ed. D. 4,3,18,3-4, który przytacza dwa responsa Trebatiusa Testy. 
do tych drugich, a nie tylko świadectwo niewiele wcześniejsze dotyczące niektórych specyficznych zastosowań skargi de dolo malo ${ }^{43}$.

Mimo wszystko pogląd tradycyjny nadal przekonuje niektórych badaczy; przyczyn takiego stanu rzeczy upatrywać można głównie w dwóch czynnikach.

$\mathrm{Z}$ jednej strony, słynnym tekstom Cycerona, które dotyczą wprowadzenia formulae de dolo, w szczególności zabawnej anegdocie o Pythiusie i Caniusie ${ }^{44}$ przypisana została wartość paradygmatu zamiast kazuistycznego przykładu zastosowania środka ochrony de dolo, bez wzięcia pod uwagę tego, że fragment de officiis, w którym została przytoczona jest zdominowany przesłaniem moralnym, które przewa-

43 Jak wskazał M. BrutTI, La problematica, I, cit., s. 130.

${ }^{44}$ Cic., de off., 3,14,58-59: Quod si vituperandi qui reticuerunt, quid de iis existimandum est, qui orationis vanitatem adhibuerunt? C. Canius, eques Romanus, nec infacetus et satis litteratus, cum se Syracusas otiandi, ut ipse dicere solebat, non negotiandi causa contulisset, dictitabat se hortulos aliquos emere velle, quo invitare amicos et ubi se oblectare sine interpellatoribus posset. Quod cum percrebuisset, Pythius ei quidam, qui argentariam faceret Syracusis, venales quidem se hortos non habere, sed licere uti Canio, si vellet, ut suis, et simul ad cenam hominem in hortos invitavit in posterum diem. Cum ille promisisset, tum Pythius, qui esset ut argentarius apud omnes ordines gratiosus, piscatores ad se convocavit et ab iis petivit, ut ante suos hortulos postridie piscarentur, dixitque quid eos facere vellet. Ad cenam tempori venit Canius; opipare a Pythio adparatum convivium, cumbarum ante oculos multitudo, pro se quisque, quod ceperat, adferebat; ante pedes Pythii pisces abiciebantur. 59: Tum Canius „,quaeso”, inquit, , quid est hoc, Pythi? tantumne piscium? tantumne cumbarum?” Et ille: ,, Quid mirum?” inquit, ,, hoc loco est Syracusis quidquid est piscium, hic aquatio, hac villa isti carere non possunt". Incensus Canius cupiditate contendit a Pythio, ut venderet. Gravate ille primo. Quid multa? impetrat. Emit homo cupidus et locuples tanti, quanti Pythius voluit, et emit instructos. Nomina facit, negotium conficit. Invitat Canius postridie familiares suos, venit ipse mature, scalmum nullum videt. Quaerit ex proximo vicino, num feriae quaedam piscatorum essent, quod eos nullos videret. „Nullae, quod sciam, " ille, , sed hic piscari nulli solent. Itaque heri mirabar quid accidisset”. Literatura dotycząca tych tekstów jest bardzo obfita; wystarczy wspomnieć tu najważniejsze prace: U. von LüBtow, Die Ursprungsgeschichte der 'exceptio doli' und der 'actio de dolo malo', [w:] Eranion Maridakis, I, Athenis 1963, s. 183 i n.; M. BRUTTI, La problematica, I, cit., s. 131 i n.; M. TALAMANCA, La 'bona fides' nei giuristi romani: „Leerformeln”, e valori dell'ordinamento, [w:] Il ruolo della buona fede oggettiva nell' esperienza giuridica storica e contemporanea, red. L. GArofalo, IV, Padova 2003, s. 131 i n. 
ża w całym dziele ${ }^{45}$. Poza tym, sam Cycero w de natura deorum definiuje iudicium de dolo malo jako everriculum malitiarum omnium ${ }^{46}$; on ma zatem świadomość, że jest to środek ogólny, mający za zadanie sankcjonowanie każdego zachowania nieuczciwego, miotły mającej sprzątnąć wszystkie nieprawidłowości z zakresu każdej dziedziny prawa.

$Z$ drugiej strony, zbyt duży walor przypisywano innym słynnym definicjom podstępu zaproponowanym przez rzymskich jurystów ${ }^{47}$ : często usiłowano zmieścić każde konkretne zastosowanie actio de dolo w granicach, i tak zbyt wąskich, definicji, zapominając o ostrzeżeniu Javolenusa, według którego omnis definitio in iure civili periculosa est: parum est enim, ut non subverti posset ${ }^{48}$.

45 Por. L. Solidoro, 'Aliud est celare, aliud tacere'(Cic., de off. 3.12.52). Proiezioni attuali di un antico dibattito sulla reticenza del venditore, «AG» 227 (2007), s. 231 i n. Mówi o „scarsa affidabilità del contesto generale del terzo libro del de officis" M. Talamanca, La 'bona fides', cit., s. 147.

${ }^{46}$ Cic., de nat. deor., 3,30,74: ... Inde illa actio „ope consilioque tuo furtum aio factum esse"; inde tot iudicia de fide mala, tutelae mandati, pro socio, fiduciae, reliqua, quae ex empto aut vendito aut conducto aut locato contra fidem fiunt, inde iudicium publicum rei privatae lege Plaetoria, inde everriculum malitiarum omnium, iudicium de dolo malo, quod C. Aquillius familiaris noster protulit; quem dolum idem Aquillius tum teneri putat, cum aliud sit simulatum, aliud actum.

${ }^{47}$ Cic., de off., 3,14,60: Stomachari Canius, sed quid faceret? Nondum enim C. Aquilius, collega et familiaris meus, protulerat de dolo malo formulas; in quibus ipsis, cum ex eo quaereretur, quid esset dolus malus, respondebat, cum esset aliud simulatum, aliud actum. Hoc quidem sane luculente, ut ab homine perito definiendi. Ergo et Pythius et omnes aliud agentes, aliud simulantes perfidi, improbi, malitiosi. Nullum igitur eorum factum potest utile esse, cum sit tot vitiis inquinatum; Ulp. 11 ad ed. D. 4,3,1,2: Dolum malum Servius quidem ita definiit machinationem quandam alterius decipiendi causa, cum aliud simulatur et aliud agitur. Labeo autem posse et sine simulatione id agi, ut quis circumveniatur: posse et sine dolo malo aliud agi, aliud simulari, sicuti faciunt, qui per eiusmodi dissimulationem deserviant et tuentur vel sua vel aliena: itaque ipse sic definiit dolum malum esse omnem calliditatem fallaciam machinationem ad circumveniendum fallendum decipiendum alterum adhibitam. Labeonis definitio vera est. Na temat tych źródeł por. zwłaszcza E. CARCATERra, 'Dolus bonus'/'dolus malus'. Esegesi di D. 4.3.1.2-3, Napoli 1970.

48 Iav. 11 ep. D. 50,17,202. Godne uwagi obserwacje M. BRUTTI, La problematica, I, cit., s. 142 dotyczące definicji Aquiliusa Gallusa: ta ,non corrisponde al proposito di tipicizzare il concetto di dolo, delimitando le situazioni cui esso può riferirsi ... . 
Jak zauważył Talamanca ${ }^{49}$, „è l'inganno ..., il dolus in contrahendo in cui praticamente si risolve in materia contrattuale il dolus praeteritus, ad essere il precipuo oggetto delle definizioni di dolo correnti nel I sec. a.C., da Aquilio Gallo a Servio Sulpicio a Labeone, mentre il dolus praesens ... non viene mai definito né da questi ultimi né da altri giuristi romani”; mimo wszystko, actio de dolo jest ,utilizzata sicuramente dallo stesso Labeone, che così restrittivamente definisce il dolus, anche al di fuori di un'attività volta ad ingannare, richiedendo soltanto la volontà rivolta a danneggiare altrui”.

Żeby lepiej zrozumieć, jaka była koncepcja podstępu w ramach skargi de dolo, najlepiej jest przyjąć metodę obiektywnej oceny sytuacji, w których była stosowana ${ }^{50}$, zrobić tak, jak radził Paulus: an dolo quid factum sit, ex facto intellegitur ${ }^{51}$.

Jurysprudencja nie tyle usiłuje wypracować teoretyczną systematykę podstępu, ile ustalić w praktyce granice zastosowania środków ochrony przeciwko podstępowi i wskazać zakres znaczeniowy tego ostatniego w oparciu o kazuistykę. Już od pierwszego starcia między definicjami podstępu a kazuistyką opisanego w Digestach można zauważyć, że wymyka się on próbom definicji.

\section{OCHRONA UMÓW PRAWNIE NIEWIĄŻĄCYCH}

Spośród wielu tekstów interesujących i znaczących dla ustalenia pojęcia podstepu, mam zamiar przeanalizować w tym miejscu tylko niektóre, wybrane spośród tych dotyczących zobowiązań z kontraktu.

Ciò emerge dall'assenza di precisi contorni del concetto di simulatio: assenza che ... è, a mio avviso, condizione, perché mediante il concetto medesimo possano individuarsi i comportamenti più svariati".

${ }^{49}$ M. Talamanca, La 'bona fides', cit., s. 173

${ }^{50} \mathrm{~W}$ tym duchu por. J. CAMIÑAs, La problemática del dolo en el derecho romano clásico, [w:] Derecho romano de obligaciones. Homenaje al profesor Murga Gener, red. J. PARICIO, Madrid 1994, s. 964.

${ }^{51}$ Ulp. 71 ad ed. D. 44,4,1,2. 
Zacznijmy od fragmentów, w których skarga z tytułu podstępu jest stosowana dla ochrony umów prawnie niewiążących. Przyjrzyjmy się przede wszystkim tekstowi Pomponiusa:

Pomp. 22 ad Sab. D. 19,5,16,1: Permisisti mihi, ut sererem in fundo tuo et fructus tollerem: sevi nec pateris me fructus tollere. nullam iuris civilis actionem esse Aristo ait: an in factum dari debeat, deliberari posse: sed erit de dolo.

Titus otrzymuje od Gaiusa pozwolenie na dokonanie zasiewu na jego gruncie i na zebranie plonów: ze zwrotów użytych dla opisania tej sytuacji wynika bez wątpienia, że doszło do zawarcia porozumienia między stronami i nie można mówić o zachowaniu tolerowanym jedynie przez grzeczność 52 .

Tytus przystępuje zatem do zasiewu, ale zebranie plonów zostaje mu uniemożliwione. Pomponius przytacza opinię Aristona, według którego nie można zastosować żadnej skargi cywilnej: tego przypadku nie da się sprowadzić ani do żadnego typowego kontraktu, ani do kontarktu nienazwanego i dlatego nie można zastosować actio praescriptis verbis, której zastosowanie, jak wiadomo, proponował Aristo w przypadku kontraktów nienazwanych mieszczących się w schemacie synallagmy ${ }^{53}$.

W opisanym przypadku nie można zastosować ogólnej skargi chroniącej zobowiązania kontraktowe nie dlatego, że brakuje datio ${ }^{54}$, za

52 Por. T. Dalla Massara, Alle origini della causa del contratto. Elaborazione di un concetto nella giurisprudenza classica, Padova 2004, s. 203.

53 Por. Ulp. 4 ad ed. D. 2,14,7,2, na temat którego zob. infra.

54 Następujący autorzy utrzymują, że ochrony odmawiano właśnie z powodu braku takiego wymogu: A.E. GIFFARD, L' 'actio incerti civilis' et le synallagma (D. 2,14,7,1), «RHDFE» 35 (1957), s. 191; F. GALLo, 'Synallagma' e 'conventio' nel contratto: ricerca degli archetipi della categoria contrattuale e spunti per la revisione di impostazioni moderne. Corso di diritto romano, I, Torino 1992, s. 100, nt. 49; R. KNÜTEL, La causa nella dottrina dei patti, [w:] Causa e contratto nella prospettiva storico-comparatistica. Atti del Congresso Internazionale Aristec (Palermo-Trapani, 7-10 giugno 1995), Torino 1997, s. 136; M. ArTner, 'Agere praescriptis verbis'. Atypische Geschäfsinhalte und klassische Formularverfahren, Berlin 2002, s. 110; L. ZHANG, Contratti innominati nel diritto romano. Impostazioni di Labeone e di Aristone, Milano 2007, s. 186. 
którą można by uznać zasiew ${ }^{55}$. Brakuje natomiast wzajemności (synallagma $)^{56}$, negotium, ponieważ nie ma świadczenia wzajemnego, które pozwalałoby zmusić stronę przeciwną do jego spełnienia ${ }^{57}$.

Nawet jeśli w tym przypadku nie może znaleźć zastosowania skarga cywilna, Aristo uważa jednak, że można rozważyć przyznanie skargi pretorskiej in factum, mającej na celu uzyskanie zwrotu kosztów poniesionych na zasiew.

$\mathrm{Na}$ końcu znajdujemy opinię Pomponiusa, zdaniem którego można przyznać, w tym samym celu, skargę z tytułu podstępu. W przypadku braku możliwości zastosowania actio civilis oraz wątpliwości co do właściwości actio in factum, autor prawidłowo decyduje, że można zastosować skargę de dolo, czyli extrema ratio rzymskiego porządku prawnego, instytucję mającą na celu zapobieganie przypadkom, kiedy to niesłusznie wyrządzona szkoda pozostanie bez odszkodowania.

Takie samo rozwiązanie proponuje Ulpian w podobnym przypadku:

Ulp. 42 ad Sab. D. 4,3,34: Si cum mihi permisisses saxum ex fundo tuo eicere vel cretam vel harenam fodere, et sumptum in hanc rem fecerim, et non patiaris me tollere: nulla alia quam de dolo malo actio locum habebit.

Wydaje mi się, że ten przypadek można odtworzyć w podobny sposób, jak ten opisany przez Pomponiusa: właściciel gruntu zezwala

55 Jak słusznie zauważył A. Burdese, Sul riconoscimento civile dei c. d. contratti innominati, «Iura» 35 1(985), s. 30; TENŻE, I contratti innominati, [w:] Derecho romano de obligaciones. Homenaje al profesor Murga Gener, red. J. PARICIO, Madrid 1994, s. 244 i T. Dalla Massara, Alle origini, cit., s. 203.

56 R. SAntoro, Il contratto nel pensiero di Labeone, «AUPA» 37 (1983), s. 299 i n. kładzie nacisk na brak przyczyny; podobnie por. T. Dalla Massara, Alle origini, cit., s. 204.

57 Tak A. Burdese, Sul riconoscimento, cit., s. 30 i 42 oraz Tenże, Divagazioni in tema di contratto romano tra forma, consenso e causa, [w:] 'Iuris vincula'. Studi in onore di Talamanca, I, Napoli 2001, s. 340. Świadczenie wzajemne da się natomiast wyodrębnić w przypadku opisanym w principium, w którym nie ma trudności z przyznaniem actio incerti civilis: Permisisti mihi cretam eximere de agro tuo ita, ut eum locum, unde exemissem, replerem: exemi nec repleo: quaesitum est, quam habeas actionem. sed certum est civilem actionem incerti competere ... 
komuś na wydobywanie z niego materiałów, ale, po dokonaniu potrzebnych do wydobycia zakupów, zmienia zdanie i uniemożliwia działania, na które wczesniej zezwoli158.

W tych przypadkach zastosowania skargi z tytułu podstępu oczywistym jest, że wykracza się poza klasyczny obszar podstępu w umowie, jako że z jednej strony nie ma zawartej umowy między stronami, a $\mathrm{z}$ drugiej strony trudno jest stwierdzić istnienie nie tylko jakiegoś oszustwa, ale nawet złej intencji w momencie udzielania pozwolenia na określone zachowanie innej osoby na własnym gruncie.

Podstęp polega tu na stworzeniu nadziei i następnie zawiedzeniu jej przy jednoczesnym spowodowaniu szkody. Albo też można powiedzieć lepiej, że podstępne było zachowanie polegające na braku chęci zwrócenia kosztów poniesionych w związku ze złamaniem danego słowa w sytuacji, gdy nie istniał inny środek uzyskania odszkodowania.

W podobnym kontekście przytoczyć można również inny tekst Ulpiana $^{59}$ :

Ulp. 25 ad ed. D. 11,7,14,2: Si cui funeris sui curam testator mandaverit et ille accepta pecunia funus non duxerit, de dolo actionem in eum dandam Mela scripsit: credo tamen et extra ordinem eum a praetore compellendum funus ducere.

${ }^{58}$ Podobnie A. Pernice, Labeo, II, I², cit., s. 217. Niepotrzebnie skomplikowana i pozbawiona podstaw źródłowych jest propozycja przedstawiona w R. Astolfi, I 'libri tres iuris civilis' di Sabino ${ }^{2}$, Padova 2001, s. 174 i n. i przyjeta przez M.F. Cursi, L'eredità dell' 'actio de dolo' e il problema del danno meramente patrimoniale, Napoli 2008, s. 112 i n., według której odmowa dominus pojawiłaby się dopiero po wydobyciu materiału, w momencie, który dla Ulpiana oznaczał nabycie własności przez tego, kto go wydobył (co potwierdza Ulp. 42 ad Sab. D. 39,5,6), podczas gdy ,secondo Sabino, occorreva un altro atto, diverso e successivo all'exemptio, affinché il minatore acquistasse la proprietà del minerale: la sua traditio" (tak R. Astolfi, I 'libri tres iuris civilis', cit., s. 175). Rozwiązanie zakładające przyznanie actio de dolo można zatem przypisać Sabinusowi, a nie Ulpianowi, który przyznałby skarge z tytułu juz nabytej własności w sposób analogiczny jak ten proponowany przez Pomp. 22 ad Sab. D. 19,5,16 pr.: ... quod si post exemptionem cretae replevero nec patieris me cretam tollere tu, agam ad exhibendum, quia mea facta est, cum voluntate tua exempta sit.

${ }^{59}$ Można tu też powołać Ulp. 24 ad ed. D. 11,6,5 pr., na temat interpretacji którego por. A. WACKE, Sul concetto di 'dolus', cit., s. 32 i n. 
Pewna osoba wzięła na siebie obowiązek zorganizowania pogrzebu spadkodawcy i na ten cel otrzymała pieniądze, a później nie wywiązała sie $\mathrm{z}$ tego. Fabius Mela, jurysta tworzący w tym samym okresie co Labeo, zaproponował, aby osoba, która zorganizował pogrzeb - zapewne dziedzic - mogła wytoczyć actio de dolo, aby uzyskać naprawienie szkody. Według Ulpiana, można było skorzystać ze środka extra ordinem, aby zmusić osobę trzecią do wywiązania się z obowiązku.

Jak twierdzi Wacke ${ }^{60}$, obowiązek przyjęty przez osobę trzecią można sprowadzić do zlecenia realizowanego post mortem mandatoris, które, według jednomyślnego poglądu doktryny, było nieważne. Skarga z tytułu podstępu zastępowałaby tu zatem actio mandati, ale tylko jeśli chodzi o naprawienie szkody.

Sanfilippo ${ }^{61}$ - który utrzymywał ważność zlecenia post mortem mandatoris - twierdził, że w tym przypadku nie da się mówić o właściwym kontrakcie zlecenia, ale jedynie o rozporządzeniu testamentowym, można powiedzieć, nienazwanym, na mocy którego testator „derogando all'ordine normale che faceva gravare l'onere dei funerali in primo luogo sull'erede, procedeva alla scelta di una persona di sua fiducia" ${ }^{\prime 2}$. Jeśli przyjmie się tę interpretację, obowiązek wynikający z takiego nienazwanego rozporządzenia miałby charakter moralny lub religijny, w każdym razie prawnie niewymagalny i jedyną możliwościa uzyskania odszkodowania byłaby actio de dolo, z wyjątkiem specyficznej ochrony w ramach nowego procesu extra ordinem wprowadzonej pod koniec okresu prawa klasycznego. Taka dalsza możliwość, znajdująca się w granicach systemu procesowego innego niż formułkowy, nie powoduje powstania problemów z punktu widzenia zasady subsydiarności skargi z tytułu podstępu.

${ }^{60}$ A. WaCKe, Sul concetto di 'dolus', cit., s. 30.

${ }^{61}$ C. SAnfilippo, Ancora un caso di 'mandatum post mortem'?, [w:] 'Sodalitas'. Scritti in onore di Guarino, V, Napoli 1984, s. 2047 i n.

62 C. SAnfilippo, Ancora un caso, cit., s. 2048. 
6. OCHRONA KONTRAKTÓW NIEUTYPIZOWANYCH NALEŻĄCYCH DO GRUPY FACIO UT DES

Innym przypadkiem stosowania skargi z tytułu podstępu jest ochrona niektórych umów nieutypizowanych, w szczególności mających za przedmiot facio ut des.

Powszechnie przyjmuje się, że actio de dolo odgrywała rolę zbliżoną do condictio causa data causa non secuta w przypadkach kiedy świadczenie wzajemne polegało na facere, a nie na dare. Jak wiadomo, poczynając od Labeona, zaczęto przyznawać tzw. actio praescriptis verbis, aby uzyskać należność przy wielu umowach nieutypizowanych; jednak dla porozumień, w których pierwsze świadczenie polegało na facere, w szczególności w wypadku facio ut des, wydaje się, że przyznawanie tej skargi budziło wiele watpliwości i że dla niektórych jurystów jedyną dostępną formą ochrony pozostała na długo actio de dolo, na mocy której uzyskiwano naprawienie szkody.

Potwierdza to Paulus w słynnym tractatus poświęconym temu zagadnieniu w odniesieniu do facio ut des $^{63}$ :

Paul. 5 quaest. D. 19,5,5,3: Quod si faciam ut des et posteaquam feci, cessas dare, nulla erit civilis actio, et ideo de dolo dabitur.

O ile dawniej wzmiankę o actio de dolo przypisywano kompilatorom justyniańskim, dziś uznaje się klasyczność rownież tego środka: jak zauważył Albanese, jeśli była „negata, o considerata dubbia ogni tutela specifica ai nova negotia, il ricorso all'a. de dolo sotto il profilo della sussidiarietà era perfettamente logico e conforme ai presupposti edittali" ${ }^{64}$.

Z tekstu Paulusa ${ }^{65}$ wyciąnąć można wniosek, że, podczas gdy inne schematy zbliżały się do kontraktów typowych - Paulus wyraźnie

${ }^{63}$ Fragment dotyczący facio ut facias (paragraf 4) jest bardzo zagmatwany, chociaż wydaje się, że na końcu przyznaje się actio praescriptis verbis.

64 B. Albanese, La sussidiarietà, cit., s. 287.

65 Paul. 5 quaest. D. 19,5,5 pr.- 4: Naturalis meus filius servit tibi et tuus filius mihi: convenit inter nos, ut et tu meum manumitteres et ego tuum: ego manumisi, tu non 
przyrównywał do ut des do umowy kupna sprzedaży, do ut facias do najmu, a facio ut facias do zlecenia - dla facio ut des nie dało się wyprowadzić takiej analogii i być może właśnie dlatego nie można było, przynajmniej zdaniem Paulusa, stworzyć odpowiedniej skargi.

Należy zauważyć, że w tym wypadku pojęcie dolus odpowiada niewywiązaniu się ${ }^{66}$ i jest w związku z tym bardzo odległe od oszustwa dokonanego w momencie zawierania umowy.

manumisisti: qua actione mihi teneris, quaesitum est. in hac quaestione totius ob rem dati tractatus inspici potest. qui in his competit speciebus: aut enim do tibi ut des, aut do ut facias, aut facio ut des, aut facio ut facias: in quibus quaeritur, quae obligatio nascatur. 1 Et si quidem pecuniam dem, ut rem accipiam, emptio et venditio est: sin autem rem do, ut rem accipiam, quia non placet permutationem rerum emptionem esse, dubium non est nasci civilem obligationem, in qua actione id veniet, non ut reddas quod acceperis, sed ut damneris mihi, quanti interest mea illud de quo convenit accipere: vel si meum recipere velim, repetatur quod datum est, quasi ob rem datum re non secuta. ... explicitus est articulus ille do ut des. 2 At cum do ut facias, si tale sit factum, quod locari solet, puta ut tabulam pingas, pecunia data locatio erit, sicut superiore casu emptio: si rem do, non erit locatio, sed nascetur vel civilis actio in hoc quod mea interest vel ad repetendum condictio. quod si tale est factum, quod locari non possit, puta ut servum manumittas, sive certum tempus adiectum est, intra quod manumittatur idque, cum potuisset manumitti, vivo servo transierit, sive $<$ de $>$ finitum non fuit et tantum temporis consumptum sit, ut potuerit debueritque manumitti, condici ei potest vel praescriptis verbis agi: quod his quae diximus convenit. sed si dedi tibi servum, ut servum tuum manumitteres, et manumisisti et is quem dedi evictus est, si sciens dedi, de dolo in me dandam actionem iulianus scribit, si ignorans, in factum civilem. 3 Quod si faciam ut des et posteaquam feci, cessas dare, nulla erit civilis actio, et ideo de dolo dabitur. 4 Sed si facio ut facias, haec species tractatus plures recipit. nam si pacti sumus, ut tu a meo debitore Carthagine exigas, ego a tuo Romae, vel ut tu in meo, ego in tuo solo aedificem, et ego aedificavi et tu cessas, in priorem speciem mandatum quodammodo intervenisse videtur, sine quo exigi pecunia alieno nomine non potest... sed tutius erit et in insulis fabricandis et in debitoribus exigendis praescriptis verbis dari actionem, quae actio similis erit mandati actioni, quemadmodum in superioribus casibus locationi et emptioni.

66 „Ilgiuristapresupponenell'inadempimento diunaparte, a frontedell'adempimento dell'altra, la condotta maliziosa della prima, richiamando senza dubbio l'azione di dolo": M.F. Cursi, L'eredità, cit., s. 90. 


\section{UWAGI KOŃCOWE}

Przeanalizowane przypadki, chociaż ograniczone jedynie do kilku przykładów, potwierdzaja, że actio de dolo sankcjonowała każde działanie charakteryzujące się niewłaściwością, przeciwko któremu poszkodowanemu nie przysługiwała inna ochrona. Często podstęp uwidaczniał się dopiero w momencie, kiedy podmiot zamierzał odnieść korzyść z sytuacji, która w danym wypadku okazałaby się szkodliwa dla osoby trzeciej i tylko dlatego niesłuszna.

Dzięki exceptio doli można było zapobiec sytuacji niewłaściwej w przypadku wniesienia skargi; natomiast actio de dolo pozwalała nie dopuścić w konkretnym wypadku do sytuacji w której pozwany nie naprawiłby szkody wyrządzonej powodowi.

Zachowanie sankcjonowane w ramach actio de dolo nie było zatem samo w sobie deliktem, ale stawało się nim, kiedy strona odmawiała naprawienia szkody korzystając z przychylnej dla niej sytuacji prawnej. Podstępne jest wobec tego zachowanie, którym podmiot wyrządza innym niesłuszną szkodę wykorzystując fakt, że porządek prawny nie przewiduje sankcji za jego postępowanie.

W braku innych środków ochrony i jeśli pretor stwierdzał istnienie iusta causa, która uzasadniałaby jego interwencję, przyznawano skargę de dolo bez potrzeby pogłębiania aspektu przedmiotowego oszustwa ze strony pozwanego. Z pewnością dolus powstał jako element psychiczny, intelektualny, ale szybko zaczął oznaczać również i przede wszystkim konsekwencję tego, czyli bezprawne zachowanie mające skutek w postaci szkody.

W ten sposób podstęp w actio de dolo stał się kategorią, w ramach której pretor miał możliwość zawrzeć bardzo różne przypadki, w których konieczne było udzielenie ochrony; w związku z brakiem ściśle określonych granic tego pojęcia, możliwe było chronienie bradzo różnorodnych sytuacji i interesów w sposób analogiczny jak przy exceptio doli ${ }^{67}$, co potwierdza Ulpian w księdze 76 ad ed. D. 44,4,2 pr.: Palam

${ }^{67}$ Por. J. CAmiñas, La problemática, cit., s. 965. 
est autem hanc exceptionem ex eadem causa propositam, ex qua causa proposita est de dolo malo actio.

Actio de dolo była zatem środkiem, który przekroczył, może bardziej niż jakikolwiek inny, granice systemu skarg stypizowanych i pozwolił wprowadzić nowe przypadki naprawienia szkody.

\section{ACtio de Dolo malo And Protection of UnBINDING AgreEMENTS}

\section{Summary}

Actio de dolo was probably introduced to the praetor's edict around 90$80 \mathrm{BC}$ at the request of $\mathrm{C}$. Aquilius, famous jurist. The thesis that it was Aquilius who as praetor in $66 \mathrm{BC}$ introduced it himself seems improbable on account of him being in charge of the quaestio de ambitu. Actio de dolo was a praetorian action in personam with an intentio in factum concepta, penal, infamating and arbitrary. It could be acquired only within a year. A previous causae cognitio of a praetor was necessary, because the action was a subsidiary means used only in absence of any other legal protection. The concept of dolus within this action was perceived very broadly as any improper behaviour causing damage the repair of which was impossible to be obtained by other means. Actio de dolo was probably an institution exceeding the typical contractual system in a furthest manner in order to introduce new possibilities of damage repair. 